\title{
Komponen Keterampilan Metakognisi Siswa Dalam Pemecahan Masalah Matematika di SMA AI-Azhar Mandiri Palu
}

\author{
Sudarman Bennu a ${ }^{*}{ }^{\star}$, Multazam ${ }^{\mathrm{b}, 2}$ \\ ${ }^{a, b}$ Pendidikan Matematika Universitas Tadulako, Jl. Soekarno Hatta Km.9 Tondo 94118 Palu, Sulawesi Tengah, Indonesia \\ 1 sudarmanbennu@gmail.com*, ${ }^{2}$ multazam03april@gmail.com \\ * Corresponding Author
}

Diterima 19 Maret 2021; Disetujui 20 Maret 2021; Diterbitkan 20 Maret 2021

\begin{abstract}
This research aims to identified and obtain a description metacognition skill components of students in SMA Al-Azhar Mandiri Palu to solving mathematical problem about linear program based on the level of mathematical ability of the students. The type of this research is qualitative research. The subject of this research is the students of class XII D SMA-Al-Azhar Mandiri Palu who have high, medium and low math ability. Data were collected by video recording, test method and interview. The results of this study indicate that subjects with high math ability, namely NF has a complete metacognition skill components that is prediction, planning, monitoring, and evaluation with regular and repetitive patterns. Subjects with medium math ability, namely $\mathrm{HN}$ also has a complete metacognition skill components that is prediction, planning, monitoring, and evaluation but the patterns is irregular and repetitive. And the subject of low math ability, namely TS has only three metacognition skill components that is prediction, planning, and evaluation with non-repetitive patterns.
\end{abstract}

KEYWORDS

Identification Metacognition skill components Mathematical problem

This is an openaccess article under the CC-BY-SA license

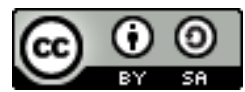

\section{Pendahuluan}

Matematika mengajarkan untuk berpikir logis, inovatif dan imajinatif (Hasibuan, 2018) merupakan satu diantara ilmu universal yang mendasari perkembangan berbagai ilmu pengetahuan dan teknologi. Hal ini tidak terlepas dari kegunaan serta manfaat dari ilmu pengetahuan dan teknologi pada kehidupan manusia sehari-hari. Ilmu pengetahuan, dan teknologi yang berkembang secara dinamis dan pesat, harus dibarengi dengan kemampuan sumberdaya manusianya, yaitu kemampuan dalam berpikir pada tingkat yang tinggi untuk memecahkan masalah dan memanfaatkan ilmu pengetahuan dan teknologi dengan sebaik-baiknya. Terdapat berbagai syarat yang harus dipenuhi untuk membentuk sumber daya manusia yang dapat menguasai dan memanfaatkan ilmu pengetahuan serta teknologi di masa yang akan datang, satu diantaranya adalah penguasaan matematika yang kuat sejak dini (Niess, 2005; Yudha, 2019).

Sumber daya manusia yang berkualitas dapat diciptakan dengan menetapkan bahwa standar kompetensi lulusan mata pelajaran matematika adalah peserta didik memiliki kemampuan berpikir logis, analitis, sistematis, kritis, dan mandiri serta memiliki kemampuan bekerjasama (Paul \& Elder, 2005). Hal ini merupakan tuntutan yang sulit yang dicapai oleh siswa yang hanya menekankan hafalan dan latihan soal yang bersifat rutin pada proses pembelajarannya. Oleh karena itu diperlukan pembelajaran yang tepat pada mata pelajaran matematika, demi tercapainya tuntutan tersebut.

Pembelajaran yang tepat untuk diterapkan pada pembelajaran matematika adalah pembelajaran yang melibatkan aktivitas kognisi, hal ini dikarenakan matematika merupakan pembelajaran yang berkaitan dengan kemampuan peserta didik memproses suatu informasi dan mengkonstruksi ide-ide secara mental. Sebagaimana yang dikemukakan oleh (Livingston, 2003) bahwa belajar matematika merupakan kegiatan mental yang tinggi, yaitu penggunaan proses berpikir dalam menyusun bagianbagian informasi yang diperoleh, dan menyimpannya dan dapat mengungkapkannya kembali, yang dalam hal ini dikenal dengan aktivitas kognisi.

Pembelajaran dengan melibatkan aktivitas kognisi adalah pembelajaran melalui usaha menumbuhkan kesadaran kognisi siswa dengan memberikan arahan agar siswa bertanya pada 
dirinya. Hal ini dilakukan agar siswa dapat memonitor pemahaman mereka mengenai apa yang sedang dipelajari. Tindakan dalam pembelajaran untuk menyadarkan kemampuan kognisi siswa merupakan upaya secara metakognisi (Phang, 2006). Sejalan dengan hal tersebut, (J. H. Flavell, 1979; Stephanou \& Mpiontini, 2017) mengemukakan bahwa pembelajaran melalui upaya penyadaran kognisi siswa merupakan pembelajaran dengan pengembangan metakognisi.

(Schoenfeld, 1985, 2016) menyatakan bahwa setiap proses pembelajaran yang memiliki masalah, akan memiliki pemecahan masalah. Pembelajaran dengan pengembangan metakognisi merupakan satu diantara pembelajaran yang membantu proses pemecahan masalah. Sebagaimana pendapat (Telaumbanua et al., 2017) yang menyatakan bahwa metakognisi merupakan alat yang dapat digunakan untuk meningkatkan kemampuan pemecahan masalah matematika siswa. (Kirkley, 2003) juga mengemukakan bahwa satu diantara aspek kemampuan yang harus dikuasai oleh siswa agar dapat menyelesaikan suatu masalah adalah kemampuan metakognisi, sehingga dapat disimpulkan bahwa terdapat keterkaitan antara kemampuan pemecahan masalah dan kemampuan metakognisi siswa. Kemampuan metakognisi dapat membantu siswa menyadari kelebihan dan kekurangan yang dimiliki, serta menyadari pengetahuan dan strategi yang benar dan bisa digunakan untuk memecahkan suatu masalah.

Pengembangan kemampuan metakognisi dalam pembelajaran pada konteks pemecahan masalah telah dilaporkan oleh beberapa peneliti. (Fatin Aliah Phang, 2006) melakukan penelitian berkaitan dengan pola-pola Problem Solving fisika dari perspektif metakognisi pada siswa sekolah dengan usia antara 14 -16 tahun dan memperoleh hasil bahwa keterampilan metakognisi memberikan pengaruh pada penyelesaian masalah fisika oleh siswa tersebut dan menunjukkan pola-pola tertentu. Selanjutnya (Kuzle, 2013) melakukan penelitian tentang pola-pola metakognisi siswa dalam pemecahan masalah matematika dari aspek geometri dinamis. Pada penelitian tersebut, (Kuzle, 2013) melakukan perbandingan pola-pola metakognisi dua subjek dalam pemecahan masalah matematika untuk masalah geometri non-rutin. Hasil penelitiannya menunjukkan terdapat elemen dan pola-pola metakognisi yang berbeda pada pemecahan masalah subjek tersebut. Berbagai hasil penelitian tersebut menunjukkan bahwa terdapat komponen-komponen keterampilan metakognisi dan pola-pola metakognisi yang berbeda-beda saat siswa melakukan proses pemecahan masalah, yang menyebabkan prosedur yang digunakan serta hasil yang diperoleh siswa pun berbeda-beda.

Tujuan penelitian ini adalah memperoleh mengidentifikasi komponen keterampilan metakognisi siswa dalam pemecahan masalah matematika di SMA Al-Azhar Mandiri Palu.

\section{Metode}

Jenis penelitian ini adalah penelitian kualitatif dengan pendekatan deskriptif kualitatif. Subjek penelitian ini adalah tiga orang siswa kelas XII D SMA Al-Azhar Mandiri Palu yang terdiri dari satu orang siswa berkemampuan matematika tinggi, satu orang siswa berkemampuan matematika sedang, dan satu orang siswa berkemampuan matematika rendah. Teknik pengumpulan data menggunakan tes, wawancara dan rekaman video. Instrumen penelitian yang digunakan dalam penelitian ini adalah instrumen utama yaitu peneliti sendiri, dan instrumen tambahan yaitu tes identifikasi komponen keterampilan metakognisi, pedoman wawancara dan Video Camera. Analisis data dalam penelitian ini mengacu pada analisis data kualitatif menurut (Miles et al., 2014) yaitu: data condensation, data display, dan conclusion drawing/verifications.

\section{Hasil dan Pembahasan}

Pengelompokan siswa berdasarkan kemampuan matematika, yaitu siswa yang berkemampuan matematika tinggi sebanyak 13 orang, berkemampuan matematika sedang sebanyak 11 orang, dan berkemampuan matematika rendah sebanyak 4 orang. Setelah dilakukan pengelompokkan, selanjutnya dipilih satu subjek yang masing-masing mewakili kelompok kategori siswa berkemampuan matematika tinggi, sedang, dan rendah. Uji kredibilitas dilakukan menggunakan triangulasi waktu, dengan memberikan dua kali tes dengan soal yang setara pada waktu yang berbeda. Masing-masing subjek menyelesaikan kedua tes tersebut dan telah kredibel, data yang diolah adalah data pada tes masalah I. Terdapat beberapa tanda pada data jawaban siswa, tanda $\{\ldots\}$ berarti subjek diam, tanda $\{-\}$ artinya ada penghilangan beberapa kata yang dianggap tidak perlu, tanda $\{--\}$ berarti 
ada penghilangan kata atau kalimat yang sangat banyak, dan huruf tebal pada kutipan menandakan komponen keterampilan metakognisi yaitu prediction, planning, monitoring dan evaluation.

\subsection{Jawaban Siswa Berkemampuan Tinggi (NF), Sedang (HN) dan Rendah (TS)}

\subsubsection{Jawaban Siswa Berkemampuan Tinggi (NF)}

Kutipan rekaman video dalam menyelesaikan masalah 1 adalah sebagai berikut:

NF1 00.01-02.01: $\{\ldots\}$ diketahui akan dibuat meja tulis dan meja makan, $\{--\}$ yang ditanya bagian a banyak meja yang harus dibuat dalam 1 bulan untuk keuntungan maksimum.

NF1 02.01-03.01: $\quad\{-\}$ Berarti penyelesaiannya $\{\ldots\}$ meja nya $x$ dan $y$, terus yang $x$ itu tahap persiapan 2, tahap pemasangan 1 , pengecatan 1 .

NF1 03.01-09.13: $\{-\}$ eh, salah.. yang ini harusnya $2 y$, baru $x+y \leq 115 .\{--\}$ dikurang, hasilnya $3 x=\{\ldots\} 195$, berarti $x=\{\ldots\} 65$.

NF1 09-13-10.21: Berarti yang ini $x+2 y=165,65+2 y=165,2 y=100, y=50$.

NF1 10.21-10.35: Jadi titik pertama itu $(65,50)$. Terus persamaan selanjutnya lagi, $2 x+$ $y=180, x+y=115$, langsung dikurangkan saja,

NF2 10.35-11.17: $\quad\{-\}$ eh, sama.. kenapa sama? $\{--\}$

NF2 13.18-13.24: Jadi dalam 1 bulan itu harus dibuat 65 meja tulis dan 50 meja makan. Oke, itu untuk bagian $a .\{-\}$

NF2 13.39-13.47: Kalau begitu, harus dicari dulu keuntungannya dalam 1 bulan $21 x+$ $27 y$,

NF2 13.47-14.51: Keuntungan 240 bulan $=2715 \times 240=\{\ldots\} 65.160\{\ldots\}$ duh, berapa ini? $\{\ldots\}$ kali 1000 ,

NF2 14.51-16.36: Berarti hasilnya $\{\ldots\}=65.160 .000$.

Hasil tes subjek NF pada masalah I dalam mengidentifikasi permasalahan serta memprediksi informasi yang akan digunakan pada penyelesaian, ditampilkan dalam Gambar 1.

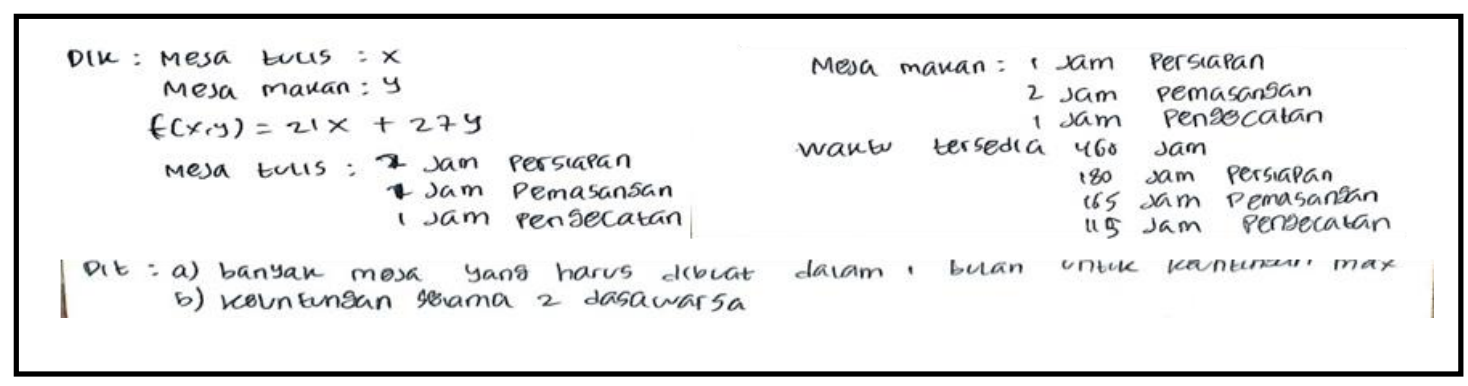

Gambar 1 Hasil identifikasi masalah $1 \mathrm{NF}$

Gambar 1 menunjukkan subjek NF melakukan proses identifikasi masalah 1 dengan menuliskan beberapa informasi yang diperolehnya dari soal serta membuat sebuah prediksi mengenai informasi yang akan digunakan untuk menyelesaikan masalah. Hasil tes tersebut memperlihatkan bahwa terdapat komponen keterampilan metakognisi prediction pada hasil penyelesaian NF untuk masalah I.

Kutipan wawancara peneliti dengan subjek NF pada masalah 1 untuk komponen keterampilan metakognisi prediction disajikan sebagai berikut:

NF1 001 P : Ketika pertama kali diberikan soal, apa yang dilakukan?

NF1 002 S : Membaca soal kemudian melakukan pemisalan.

NF1 009 P : Setelah itu, apa lagi yang dilakukan?

NF1 010 S: Kemudian setelah itu, diketahui lagi meja tulis dan meja makan 3 tahap. Kalau meja tulis 2 jam tahap persiapan, 1 jam pemasangan, dan 1 jam pengecatan. Kalau yang meja makan, 1 jam persiapan, 2 jam pemasangan, dan 1 jam pengecatan. Jadi kan disoal jg dibilang waktu yang tersedia keseluruhan untuk pembuatan kedua meja itu 460 jam. Terus kemudian yang tahap persiapan itu 180 jam, pemasangan 165, dan 115 jam pengecatan.

NF1 011 P : Kemudian, yang ditanyakan dari soal itu apa? 
NF1 012 S : Kalau yang ditanya itu ada dua, yang bagian $\boldsymbol{a}$ itu banyak meja yang dibuat dalam 1 bulan untuk keuntungan yang maksimum. Kalau yang bagian $b$ nya, keuntungannya yang diperoleh selama 2 dasawarsa.

Berdasarkan hasil tes masalah 1 subjek NF dan wawancara mendalam diperoleh informasi bahwa subjek dapat menjelaskan informasi-informasi yang diperolehnya dari masalah yang diberikan baik secara lisan maupun tulisan. Subjek terlebih dahulu membaca soal, kemudian memberikan prediksi dengan cara membuat pemisalan, serta memberikan penjelasan mengenai informasi dan model matematika atau persamaan yang ditulisnya secara lisan.

Hasil tes subjek NF pada masalah 1 dalam menetapkan tujuan, merencanakan penyelesaian, memilih strategi yang tepat, dan mengurutkan tahap-tahap yang akan dilakukan dalam pemecahan masalah, ditampilkan dalam Gambar 2.

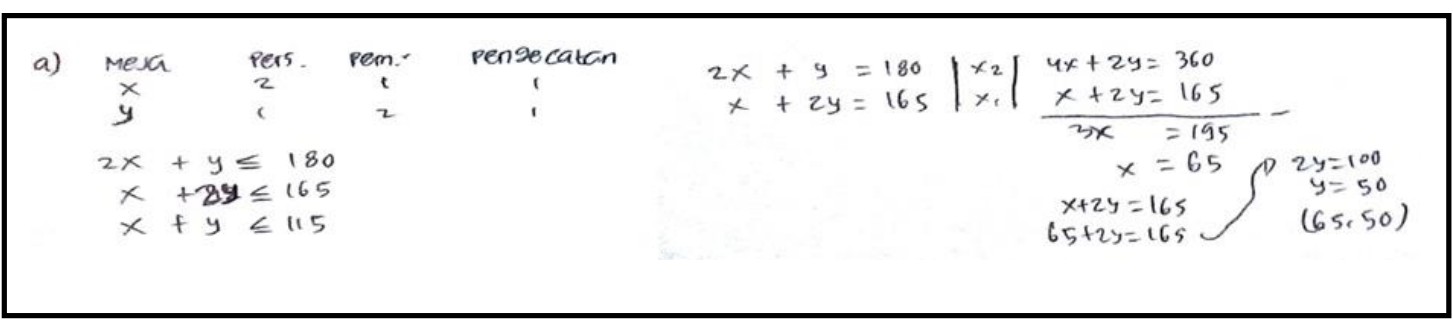

Gambar 2 Hasil Tes NF pada Masalah 1 untuk Komponen keterampilan Planning

Gambar 2 menunjukkan subjek NF melakukan proses perencanaan penyelesaian masalah 1 dengan membuat sebuah bagan sederhana dan beberapa pertidaksamaan yang akan digunakan dalam memecahkan masalah 1 serta terlihat juga beberapa langkah penyelesaian yang dipilih oleh NF. Hasil tes tersebut memperlihatkan bahwa terdapat komponen keterampilan metakognisi planning pada hasil penyelesaian NF untuk masalah 1.

Kutipan wawancara peneliti dengan subjek NF pada masalah 1 untuk komponen keterampilan metakognisi planning ditampilkan sebagai berikut:

NF1 013 P : Setelah diperoleh yang diketahui dan yang ditanyakan, kemudian apa yang selanjutnya dilakukan?

NF1 014 S : Dibentuk ke dalam pertidaksamaan dia.

NF1 $015 \mathrm{P}$ : Kenapa dibentuk ke dalam pertidaksamaan?

NF1 $016 \mathrm{~S}$ : Karena berdasarkan yang diketahui kalau waktunya itu dibatasi, berarti nda boleh lebih, tapi boleh sama atau kurang.

NF1 017 P : Darimana didapat pertidaksamaannya?

NF1 $018 \mathrm{~S}$ : Dari masing-masing jam yang disetiap tahap meja makan dan meja tulis.

NF1 $019 \mathrm{P}$ : Selanjutnya, apa lagi yang dilakukan?

NF1 $020 \mathrm{~S}$ : Dicari berapa jumlah meja makan dan meja tulis yang dibuat dalam 1 bulan.

NF1 $021 \mathrm{P}$ : Cara apa yang digunakan?

NF1 $022 \mathrm{~S}$ : Uji titik dan eliminasi persamaan.

NF1 $023 \mathrm{P}$ : Bagaimana caranya?

NF1 $024 \mathrm{~S}$ : Dibuat semua dulu dia dalam bentuk persamaan, kemudian dieliminasi persamaan 1 dan 2, kemudian persamaan 1 dan 3, baru persamaan 2 dan 3. Kebetulan disini dari eliminasi ketiganya itu jawabannnya sama yaitu $(65,50)$

Berdasarkan hasil tes masalah 1 dan wawancara mendalam subjek NF diperoleh informasi bahwa subjek dapat melakukan proses perencanaan dan penyusunan strategi yang akan digunakannya dalam pemecahan masalah. Kemudian subjek juga dapat menjelaskan kembali tahapan perencanaan serta strategi penyelesaian masalah yang dipilihnya secara lisan dan tulisan. Subjek terlebih dahulu membuat pertidaksamaan berdasarkan informasi yang diperoleh dari soal, kemudian melakukan perencanaan melalui strategi yang akan digunakan, serta memberikan penjelasan mengenai perencanaan dan strategi yang ditulisnya. 
Hasil tes subjek NF pada masalah 1 dalam memonitor setiap langkah yang dilakukan, melakukan perhitungan dengan teliti, dan memperbaiki kesalahan dalam pemecahan masalah, ditampilkan dalam Gambar 3.

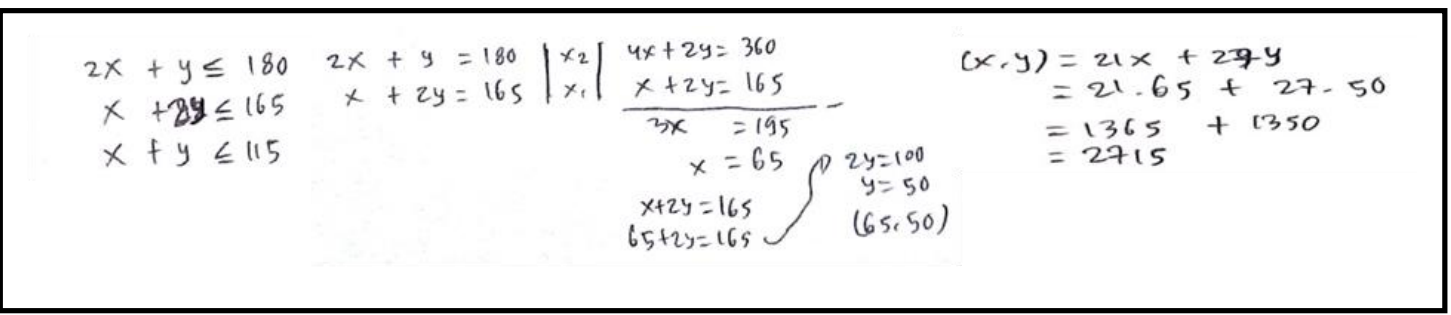

Gambar 3 Hasil Tes NF pada Masalah 1 untuk komponen keterampilan Monitoring

Gambar 3 menunjukkan subjek NF melakukan pengecekkan dan perbaikan kesalahan perhitungan pada saat pemecahan masalah. Hasil tes tersebut memperlihatkan bahwa terdapat komponen keterampilan metakognisi monitoring pada hasil penyelesaian NF untuk masalah 1.

Informasi lebih mendalam mengenai hasil penelitian diperoleh melalui wawancara. Berbeda dengan komponen keterampilan metakognisi lainnya, beberapa wawancara yang dilakukan pada komponen keterampilan metakognisi monitoring merujuk pada kutipan video, karena proses monitoring tidak dapat dengan mudah dilihat berdasarkan tes. Kutipan wawancara peneliti dengan subjek NF pada masalah 1 untuk komponen keterampilan metakognisi monitoring ditampilkan sebagai berikut:

NF1 027 P : Disini terlihat ada beberapa coretan yang terlihat, kemudian ada angka yang diganti, itu kenapa?

NF1 $028 \mathrm{~S}$ : Kalo yang $2 \boldsymbol{y}$ dan $\mathbf{2 7 y}$ ini saya ganti karena salah lihat.

NF1 029 P: Terus terlihat tadi setelah dapat titiknya $(65,50)$, beberapa kali NF diam terus seperti ragu-ragu, itu kenapa?

NF1 030 S : Itu karena saya bingung, soalnya setelah dieliminasi semua titiknya sama semua yang didapat.

NF1 031 P: Kemudian, apa yang menyebabkan NF memilih titik $(65,50)$ sebagai titik maksimumnya?

NF1 032 S: Karena setelah saya cek, perhitunganku sudah benar semua, berarti titiknya memang $(65,50)$.

Berdasarkan hasil tes masalah 1 subjek NF dan wawancara mendalam diperoleh informasi bahwa subjek dapat memonitor langkah yang dilakukan dan memperbaiki kesalahan dalam memecahkanan masalah. Kemudian subjek juga dapat menjelaskan kembali tahapan monitoring dan langkah yang dipilihnya secara lisan dan tulisan. Subjek terlebih dahulu melakukan perhitungan dan pengecekkan terhadap langkah yang dilakukannya, kemudian melakukan perbaikan jika terjadi kesalahan atau kekeliruan dalam memecahkan masalah, serta memberikan penjelasan mengenai proses monitoring yang ditulisnya.

Hasil tes subjek NF dalam menilai hasil penyelidikan yang dilakukan, menilai pencapaian tujuan, menilai kesesuaian prosedur yang digunakan, dan membuat kesimpulan, ditampilkan dalam Gambar 4

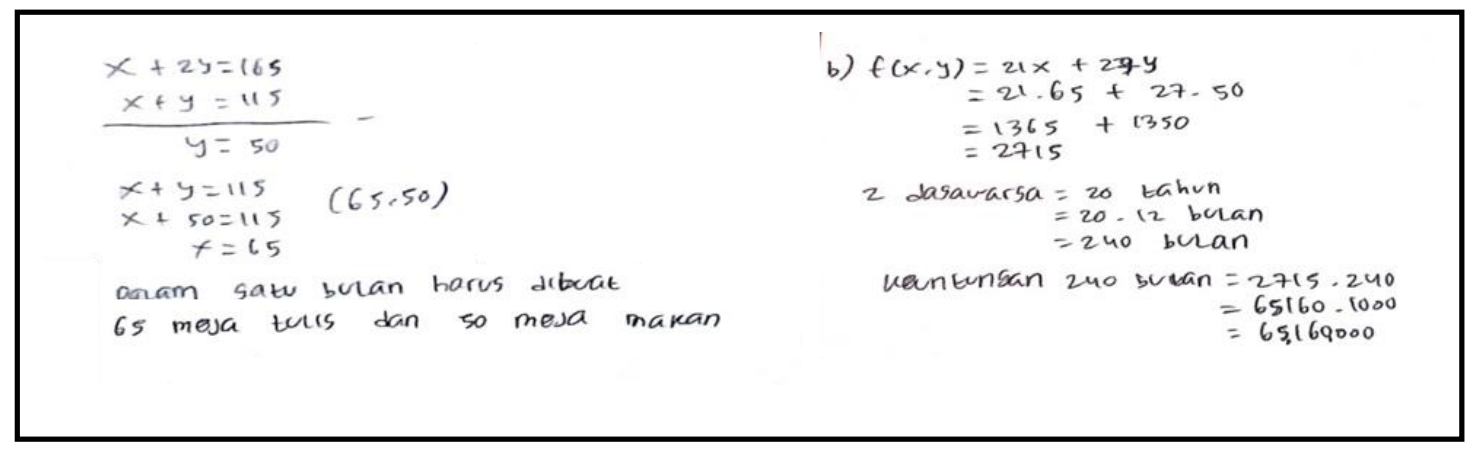

Gambar 4 Hasil Tes NF pada Masalah 1 untuk komponen keterampilan Evaluation 
Gambar 4 menunjukkan subjek NF melakukan proses pengambilan kesimpulan berdasarkan prosedur dan langkah-langkah yang telah dilakukan. Hasil tes tersebut memperlihatkan bahwa terdapat komponen keterampilan metakognisi evaluation pada hasil penyelesaian NF untuk masalah 1 .

Kutipan wawancara peneliti dengan subjek NF pada masalah 1 untuk komponen keterampilan metakognisi evaluation ditampilkan sebagai berikut:

NF1 023 P : Bagaimana caranya?

NF1 024 S : Dibuat semua dulu dia dalam bentuk persamaan, kemudian dieliminasi persamaan 1 dan 2, kemudian persamaan 1 dan 3, baru persamaan 2 dan 3. Kebetulan disini dari eliminasi ketiganya itu jawabannnya sama yaitu $(65,50)$.

NF1 025 P : $(65,50)$ itu apanya?

NF1 026 S : Itu $(x, y)$ nya, berarti meja tulis yang harus dibuat selama 1 bulan itu 65 meja tulis dan 50 meja makan.

NF1 039 P : Setelah itu, apa lagi yang dilakukan?

NF1 $040 \mathrm{~S}$ : Nanti kan didapat keuntungannya selama 1 bulan itu, trus dicari dulu 2 dasawarsa itu berapa tahun, ternyata 20 tahun, berarti dikali 12, didapat lah 240 bulan. 240 bulan itu dikalikan dengan keuntungannya dalam 1 bulan, berarti 2715 kali 240, dapat 65160 atau 65160000.

NF1 $041 \mathrm{P}$ : Berarti jawaban yang diperoleh?

NF1 042 S : Untuk 1 bulan harus dibuat 65 meja tulis dan 50 meja makan, kemudian keuntungan perbulannya itu 2.715.000. Untuk 2 dasawarsa itu 65.160.000.

NF1 043 P : Sudah itu jawaban akhirnya?

NF1 044 S : Iya

Berdasarkan hasil tes masalah 1 dan wawancara mendalam subjek NF diperoleh informasi bahwa subjek dapat menilai hasil penyelidikan yang dilakukan, menilai pencapaian tujuan, menilai kesesuaian prosedur yang digunakan, dan membuat kesimpulan dalam memecahkan masalah. Kemudian subjek juga dapat menjelaskan kembali proses evaluation dan kesimpulan yang dibuatnya secara lisan dan tulisan. Subjek terlebih dahulu menilai kesesuaian prosedur dan langkah yang digunakan dalam memecahkan masalah, kemudian menentukan hasil penyelidikan berdasarkan prosedur yang dilakukan dan menilai pencapaian tujuan dari masalah yang diberikan, kemudian membuat kesimpulan akhir dari jawaban yang diperoleh, serta memberikan penjelasan mengenai proses evaluasi yang ditulisnya.

\subsubsection{Jawaban Siswa Berkemampuan Sedang (HN)}

Kutipan rekaman video dalam menyelesaikan masalah 1 adalah sebagai berikut:

HN1 00.01-00.27 : \{...\} Kalau dari soal, berarti kita buat fungsi optimumnya dulu yaitu $f(x, y)=\{--\}$ berarti fungsi optimumnya $21 x+27 y$

HN1 00.27-01.00 : Terus yang diketahui $\{\ldots\}$ meja tulis dan meja makan. $\{-\}$ Terus untuk membuat 1 meja tulis atau $x$ itu ada tiga tahapan, 2 jam tahap I persiapan TI, 1 jam pemasangan TII, trus 1 jam TIII. $\{-\}$

HN1 01.09-01.20 : Baru di soal dibilang tahap I tersedia 180 jam, berarti $2 x+y \leq$ 180. Terus tahap II nya tersedia 165 jam, berarti jadinya $x+2 y \leq$ 165, dan sisanya untuk tahap III $x+y \leq\{\ldots\} 460\{-\}$

HN1 01.22-11.01 : Tunggu dulu, berarti 460 kurang $345\{\ldots\}$ oh iya, betul sudah 115. Terus ini masing-masing kita cari titiknya (membuat tanda panah ). $\{--\}$. Trus kalo $y$ nya $0, x$ nya 165 . Sama yang $x+y=115$, dia $x$ nya 0 dan $y$ nya $115, y$ nya 0 berarti $x$ nya yang 115 . $\{--\}$ sama yang $(x, y)$ nya itu $(65,50) 21$ kali 65 ditambah 27 kali $50 \mathrm{mmm} . .\{\ldots\}$ hasilnya 2.715.

HN1 11.01-11.19 : Berarti untuk pertanyaan yang $\boldsymbol{a}$ jawabannya itu $(\mathbf{6 5 , 5 0 )}$ tulis dibelakang. $\{-\}$ Trus yang $b$ berapa besar keuntungan maksimum yang diperoleh selama 2 dasawarsa, $\{-\}$

HN1 11.45-12.23 : 1 dasawarsa kayaknya 8 bulan $\{--\}(65,50)$ itu kan tadi keuntungannya 2.175 terus ini diperoleh dalam 1 bulan. 
HN1 12.23-13.49 : \{...\} eh, kayaknya 1 dasawarsa itu 4 bulan. $\{\ldots\}$ terus 1 dasawarsa kan 4 bulan, kalo 2 dasawarsa itu berarti 8 bulan. $\{-\}$ berarti kalo 2 dasawarsa itu berarti 8 kali $2715\{\ldots\}$ itu 21.720 atau 21.720 .000 .

HN1 13.49-13.54 : Jadi, selama 2 dasawarsa keuntungannya itu $R$ p21. 720.000

Hasil tes subjek HN pada masalah 1 dalam mengidentifikasi permasalahan serta memprediksi informasi yang akan digunakan pada penyelesaian, ditampilkan sebagai berikut:

a. $f(x, y)=21 x+27 y \quad \begin{aligned} & \text { mijas tulis }(x)=2 . T I+T I I+T \text { IIII } \\ & \text { meja maman }(y)=T I+2 T I I+T L I I\end{aligned}$

\section{Gambar 5 Hasil Identifikasi Masalah 1 HN}

Gambar 5 menunjukkan subjek HN melakukan proses identifikasi masalah 1, dengan menuliskan beberapa informasi yang diperolehnya dari soal serta membuat sebuah prediksi mengenai informasi yang akan digunakan untuk menyelesaikan masalah. HN tidak menuliskan informasi yang diperolehnya secara rinci, namun $\mathrm{HN}$ hanya menuliskan informasi-informasi tersebut secara singkat untuk digunakan dalam menyelesaikan masalah. Hasil tes tersebut memperlihatkan bahwa terdapat komponen keterampilan metakognisi prediction pada hasil penyelesaian $\mathrm{HN}$ untuk masalah 1.

Kutipan wawancara peneliti dengan subjek HN pada masalah 1 untuk komponen keterampilan metakognisi prediction disajikan sebagai berikut:

HN1 $001 \mathrm{P}$ : Ketika diberikan soal, apa pertama kali yang dilakukan?

HN1 $002 \mathrm{~S}$ : Membaca soal terus mencari tahu $\boldsymbol{f}(\boldsymbol{x}, \boldsymbol{y})$ nya untuk mencari nilai optimum.

HN1 003 P : Setelah itu?

HN1 $004 \mathrm{~S}$ : Menuliskan yang diketahui

HN1 $005 \mathrm{P}$ : Apa yang diketahui dari soal?

HN1 $006 \mathrm{~S}$ : Yang diketahui itu $(\boldsymbol{x}, \boldsymbol{y})$ nya, $\boldsymbol{x}$ nya itu saya misalkan meja tulis dan meja makan sebagai $\boldsymbol{y}$, terus kan disini dibilang ada 3 tahap untuk membuat meja tulis dan meja makan. Pertama persiapan, pemasangan dan pengecatan. Kemudian dibuatkan seperti ini, meja tulis berapa jam untuk per-tahap. Kalo meja tulis disini kan dibilang 2 jam untuk persiapan, 1 jam pemasangan sama 1 jam pengecatan. Sedangkan meja makan itu dia butuh persiapan 1 jam, pemasangan 2 jam, dan pengecatan 1 jam. Terus waktu keseluruhannyanya terbatas 460 jam, dan dibagi masing-masing tahap 180 jam, 165 jam, dan sisanya 115 jam.

HN1 $007 \mathrm{P}$ : Apa yang ditanyakan dari soal?

HN1 $008 \mathrm{~S}$ : Nilai optimum atau maksimum yang bisa dicari.

Berdasarkan hasil tes masalah 1 subjek HN dan wawancara mendalam diperoleh informasi bahwa subjek dapat mengumpulkan informasi-informasi yang diperolehnya dari soal yang diberikan. Subjek juga dapat mengemukakan kembali informasi yang diperolehnya sesuai dengan masalah yang diberikan secara lisan dan tulisan. Informasi dalam tulisan HN tidak secara rinci memperlihatkan informasi yang diperolehnya, namun proses prediction tersebut terlihat pada hasil wawancara dan rekaman video. Subjek terlebih dahulu membaca soal, kemudian memberikan prediksi dengan menuliskan informasi yang diperoleh secara singkat, serta memberikan penjelasan mengenai informasi dan model matematika atau persamaan yang ditulisnya.

Hasil tes subjek HN pada masalah 1 dalam menetapkan tujuan, merencanakan apa yang akan dilakukan, memilih strategi yang tepat, dan mengurutkan tahap-tahap yang akan dilakukan dalam pemecahan masalah, ditampilkan dalam Gambar 6. Gambar 6. menunjukkan subjek HN melakukan proses perencanaan penyelesaian masalah 1 , dengan membuat beberapa pertidaksamaan yang akan digunakan dalam memecahkan masalah 1 serta terlihat juga beberapa langkah penyelesaian yang dipilih oleh $\mathrm{HN}$ dan sketsa grafik yang dibuatnya. Hasil tes tersebut memperlihatkan bahwa terdapat komponen keterampilan metakognisi planning pada hasil penyelesaian HN untuk masalah 1.

Kutipan wawancara peneliti dengan subjek HN pada masalah 1 untuk komponen keterampilan metakognisi planning ditampilkan sebagai berikut:

HN1 $009 \mathrm{P}$ : Setelah mengetahui apa yang ditanyakan, selanjutnya apa yang dilakukan? 
HN1 $010 \mathrm{~S}$ : Langsung buat pertidaksamaannya.

HN1 $011 \mathrm{P}$ : Kenapa langsung bisa disimpulkan bahwa yang dibuat itu pertidaksamaan?

HN1 $012 \mathrm{~S}$ : Dibuat pertidaksamaan karena waktunya terbatas 460, tapi dibagi masingmasing tahap 180, 165, dan 115.

HN1 013 P : Setelah itu?

HN1 014 S : Dibentuk pertidaksamaannya dari tahap I meja tulis itu 2 jam dan 1 jam meja makan, kemudian waktunya dibatasi 180 . Begitu juga dengan tahap II dan tahap III untuk masing-masing meja.

HN1 019 P : Setelah itu?

HN1 $020 \mathrm{~S}$ : Saya ubah dulu kebentuk persamaan untuk cari titik-titiknya.

HN1 $025 \mathrm{P}$ : Setelah dapat titik-titiknya?

HN1 $026 \mathrm{~S}$ : Kemudian dibuatkan grafik dan dimasukkan ke grafik.

HN1 $033 \mathrm{P}$ : Coba jelaskan bagaimana bisa dapat titik maksimumnya melalui grafik ini?

HN1 $034 \mathrm{~S}$ : Pertama dibuat dulu diagramnya kan, baru disini kan dilihat titiknya rata-rata kelipatan 30, jadi saya buat begini supaya mempermudah. Selanjutnya sudah diketahui titik-titiknya kemudian dimasukkan ke diagramnya. Yang pertama itu $(0,180)$ dan $(90,0)$, tentukan titiknya dan buat garis. Setelah itu diperpanjang. Begitu juga dengan titik-titik yang lain.

HN1 $037 \mathrm{P}$ : Kenapa diarsirnya kearah bawah, bukan ke arah atas?

HN1 $038 \mathrm{~S}$ : Karena saya masukkan nilai nya yang dibawah sini, saya ambil titik (30,0), kemudian masukkan ke pertidaksamaannya. Kalo seandainya memenuhi, berarti arsirnya ke arah bawah. Kemudan berlaku juga untuk pertidaksamaan yang lain, titik yang saya masukkan juga sama.

HN1 $039 \mathrm{P}$ : Setelah diperoleh grafiknya, apa lagi yang dilakukan?

HN1 $040 \mathrm{~S}$ : Setelah itu didapat sudah daerah penyelesaiannya. Disini diketahui ada 4 titik, yaitu $(0,0),(0,90),(90,0)$ dan satu titik yang belum kita ketahui. Nilai titik yang belum kita ketahui itu bisa diperoleh melalui 3 garis yang saling berpotongan. Caranya dengan disubtitusi saja persamaannya itu ke persamaan lainnya. Terus dapat $y$ nya itu 50, berarti kalo $y$ nya 50 maka $x$ nya 65 .

HN1 $041 \mathrm{P}$ : Setelah dapat $x$ dan $y$, apa lagi yang dilakukan?

HN1 $042 \mathrm{~S}$ : Setelah itu sudah didapat semua titik-titiknya, di uji satu-satu ke dalam fungsi optimum.

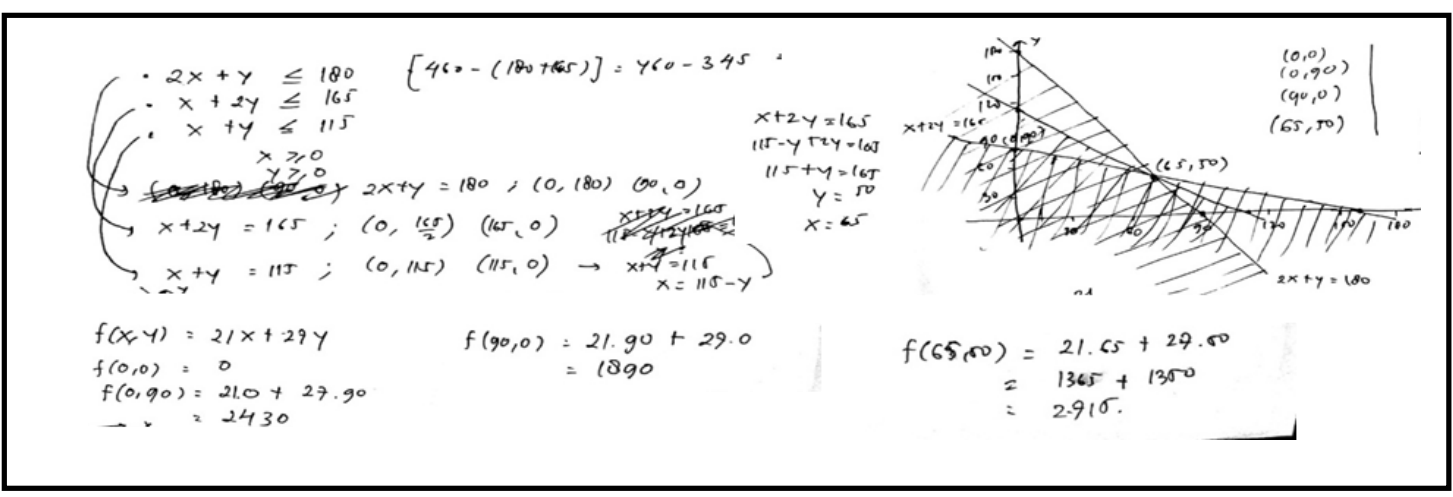

Gambar 6 Hasil Tes HN pada Masalah 1 untuk komponen keterampilan Planning

Berdasarkan hasil tes masalah 1 dan wawancara mendalam subjek HN diperoleh informasi bahwa subjek dapat melakukan proses perencanaan dan strategi yang digunakannya dalam pemecahan masalah. Subjek juga dapat menjelaskan kembali tahapan perencanaan serta strategi penyelesaian masalah yang dipilihnya secara lisan dan tulisan. Subjek terlebih dahulu membuat pertidaksamaan berdasarkan informasi yang diperoleh dari soal, kemudian melakukan perencanaan melalui strategi yang akan digunakan yaitu menggunakan grafik, serta memberikan penjelasan mengenai perencanaan dan strategi yang ditulisnya. 
Hasil tes subjek HN pada masalah 1 dalam memonitor setiap langkah yang dilakukan, melakukan perhitungan dengan teliti, dan memperbaiki kesalahan dalam pemecahan masalah, ditampilkan dalam Gambar 7.

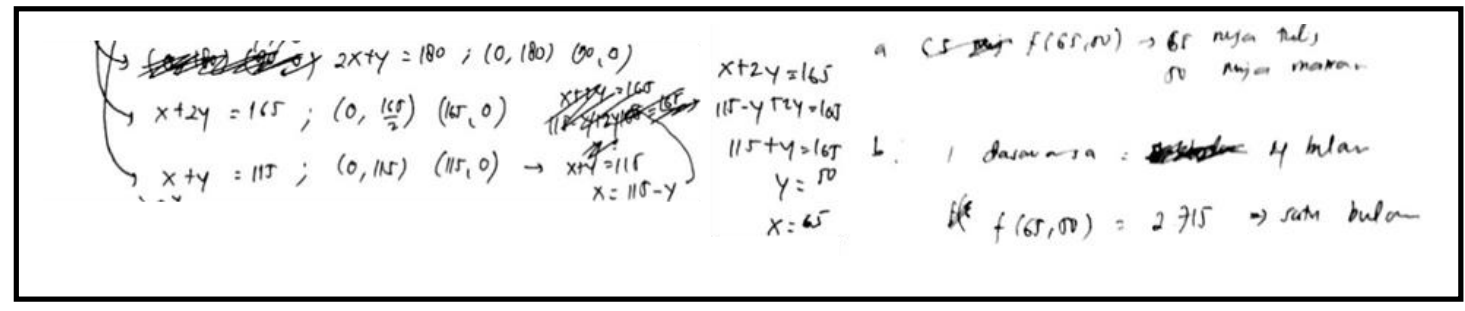

Gambar 7 Hasil Tes HN pada Masalah 1 untuk komponen keterampilan Monitoring

Gambar 7 menunjukkan subjek HN melakukan perbaikan kesalahan perhitungan dan penulisan pada saat pemecahan masalah. Hasil tes tersebut memperlihatkan bahwa terdapat komponen keterampilan metakognisi monitoring pada hasil penyelesaian $\mathrm{HN}$ untuk masalah 1.

Informasi lebih mendalam mengenai hasil penelitian diperoleh melalui wawancara. Berbeda dengan komponen keterampilan metakognisi lainnya, beberapa wawancara yang dilakukan pada komponen keterampilan metakognisi monitoring merujuk pada kutipan video, karena proses monitoring tidak dapat dengan mudah dilihat berdasarkan tes dan wawancara. Kutipan wawancara peneliti dengan subjek HN pada masalah 1 untuk komponen keterampilan metakognisi monitoring ditampilkan sebagai berikut:

HN1 015 P : Dari rekaman tadi sepertinya HN agak ragu-ragu tentang 115 ini, itu kenapa?

HN1 $016 \mathrm{~S}$ : Sepertinya karena takut salah hitung kak, jadi saya pikir-pikir ulang.

HN1 $051 \mathrm{P}$ : Disini kenapa 8 bulan dicoret terus diganti 4 bulan?

HN1 $052 \mathrm{~S}$ : Karena itu tadi kak, saya nda tau 1 dasawarsa itu berapa bulan, jadi pake feeling saja kira-kira berapa. Awalnya saya pikir 8 bulan, tapi setelah saya pikir-pikir kayaknya 4 bulan.

HN1 $053 \mathrm{P}$ : Tadi beberapa kali HN bertanya dan ragu-ragu dalam mengerjakan soal, beberapa kali $\mathrm{HN}$ juga berhenti dan diam, itu kira-kira kenapa?

HN1 054 S : Karena lagi berpikir kak, mengecek juga apakah jawabanku sudah benar atau tidak.

Berdasarkan hasil tes masalah 1 dan wawancara mendalam subjek HN diperoleh informasi bahwa subjek dapat memonitor langkah yang dilakukan dan memperbaiki kesalahan dalam memecahkan masalah. Subjek juga dapat menjelaskan kembali tahapan keterampilan metakognisi monitoring dan langkah yang dipilihnya secara lisan dan tulisan. Subjek terlebih dahulu melakukan perhitungan dan pengecekkan terhadap langkah yang dilakukannya, kemudian melakukan perbaikan jika terjadi kesalahan atau kekeliruan dalam memecahkan masalah, serta memberikan penjelasan mengenai proses monitoring yang ditulisnya.

Hasil tes subjek HN dalam menilai hasil penyelidikan yang dilakukan, menilai pencapaian tujuan, menilai kesesuaian prosedur yang digunakan, dan membuat kesimpulan, ditampilkan dalam Gambar 8.

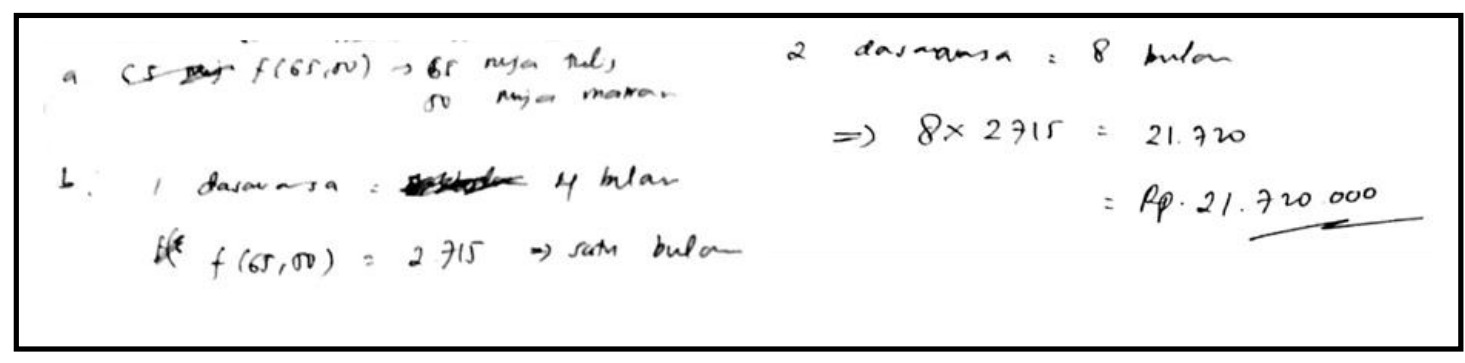

Gambar 8 Hasil Tes HN pada Masalah 1 untuk komponen keterampilan Evaluation

Gambar 8 menunjukkan subjek HN melakukan proses pengambilan kesimpulan berdasarkan prosedur dan langkah-langkah yang telah dilakukan. Hasil tes tersebut memperlihatkan bahwa 
terdapat komponen keterampilan metakognisi evaluation pada hasil penyelesaian $\mathrm{HN}$ untuk masalah 1.

Kutipan wawancara peneliti dengan subjek HN pada masalah 1 untuk komponen keterampilan metakognisi evaluation ditampilkan sebagai berikut:

HN1 $043 \mathrm{P}$ : Setelah itu?

HN1 $044 \mathrm{~S}$ : Kalo dilihat kan disoal, pertanyaannya kan berapa meja tulis dan meja makan yang dapat dibuat. Berarti kita liat kan nilai yang paling maksimum disini dari ke lima titik itu kan $(65,50)$. Jadi kalo yang buat pertanyaan pertama itu, jawabannya 65 meja tulis dan 50 meja makan.

HN1 $049 \mathrm{P}:$ Kemudian untuk yang bagian $b$ ?

HN1 $050 \mathrm{~S}$ : Untuk yang bagian b, yang saya jawab sih, karena saya tidak tau 1 dasawarsa itu berapa bulan atau berapa tahun, maka saya tuliskan bahwa 1 dasawarsa itu 4 bulan. Karena disini yang ditanyakan 2 dasawarsa, maka saya jawab 8 bulan. Nah ini kan karena tadi sudah didapat $x$ nya itu 50 dan $y$ nya itu 65 , terus nilai maksimumnya 2.715.000. nah kalo ditanya 2 dasawarsa, berarti tinggal dikali saja, 8 kali 2.715.000, terus didapat hasilnya $\mathbf{2 1 . 7 2 0 . 0 0 0}$.

Berdasarkan hasil tes masalah 1 subjek $\mathrm{HN}$ dan wawancara mendalam diperoleh informasi bahwa subjek dapat menilai hasil penyelidikan yang dilakukan, menilai pencapaian tujuan, menilai kesesuaian prosedur yang digunakan, dan membuat kesimpulan dalam memecahkan masalah. Kemudian subjek juga dapat menjelaskan kembali proses evaluation dan kesimpulan yang dibuatnya secara lisan dan tulisan. Subjek terlebih dahulu menilai kesesuaian prosedur dan langkah yang digunakan dalam memecahkan masalah, kemudian menentukan hasil penyelidikan berdasarkan prosedur yang dilakukan dan menilai pencapaian tujuan dari masalah yang diberikan, kemudian membuat kesimpulan akhir dari jawaban yang diperoleh, serta memberikan penjelasan mengenai proses evaluasi yang ditulisnya.

\subsubsection{Jawaban Siswa Berkemampuan Rendah (TS)}

Berikut adalah kutipan rekaman video TS dalam menyelesaikan masalah 1 (TS1) :

TS1 00.01-04.49: \{...\} Diketahui sebuah perusahaan akan membuat dua jenis meja yaitu meja tulis dan meja makan. $\{--\}$. Setiap pekerjaan membutuhkan waktu, pada meja tulis 2 jam, 1 jam, terus yang ketiga 1 jam. $\{--\}$

TS1 06.56-07.11 : Untung yang diperoleh untuk 1 meja tulis 21k (21.000) dan meja makan 27k (27.000). Jadi kita misalkan tahap 1 itu a, tahap 2 itu b, tahap 3 itu c. Jadi tahap 1 meja makan 1 jam dan meja tulis 2 jam,

TS1 07.11-10.26: Jadi $2 \boldsymbol{a}+\boldsymbol{a}=\mathbf{1 8 0}$ jam, itu $3 \boldsymbol{a}$ jadi $\{\ldots\}$ disini 180, terus $\boldsymbol{a}=\mathbf{6 0}$ jam. Terus $\{\ldots\}$ tahap kedua $b+2 b=165$, trus $3 \mathrm{~b}=165, \mathrm{~b}=55$ jam. Terus yang ketiga ituu $\{\ldots\} c+c=115,2 \mathrm{c}=115$, berarti $\mathrm{c}=$ $\{\ldots\}$ 57,5.

Hasil tes subjek TS pada masalah 1 dalam mengidentifikasi permasalahan serta memprediksi informasi yang akan digunakan pada penyelesaian, ditampilkan dalam Gambar 9.

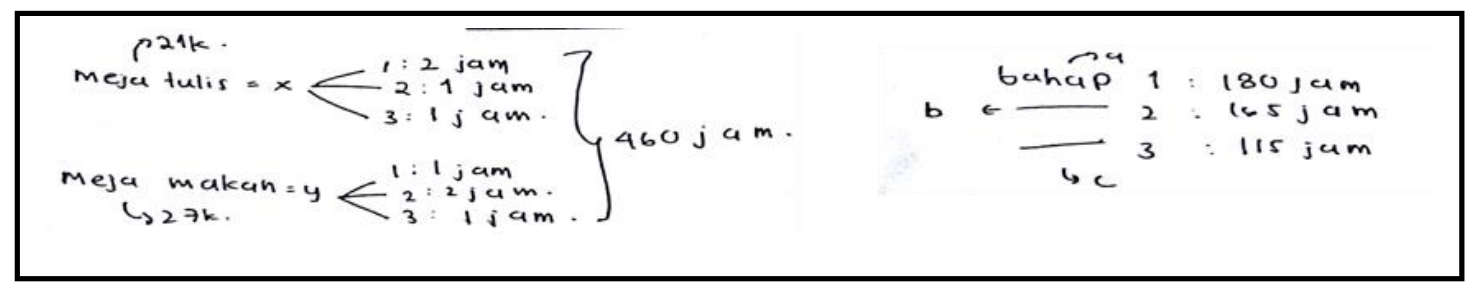

Gambar 9. Hasil Identifikasi Masalah 1 TS

Gambar 9 menunjukkan subjek TS melakukan proses identifikasi masalah 1, terlihat bahwa TS menuliskan beberapa informasi yang diperolehnya dari soal serta membuat sebuah bagan sederhana dan prediksi mengenai informasi yang akan digunakan untuk menyelesaikan masalah. TS tidak menuliskan informasi yang diperolehnya secara rinci, namun TS hanya menuliskan informasiinformasi tersebut secara singkat untuk digunakan dalam menyelesaikan masalah. Hasil tes tersebut 
memperlihatkan bahwa terdapat komponen keterampilan metakognisi prediction pada hasil penyelesaian TS untuk masalah 1.

Kutipan wawancara peneliti dengan subjek TS pada masalah 1 untuk komponen keterampilan metakognisi prediction disajikan sebagai berikut:

TS1 $001 \mathrm{P}$ : Ketika diberikan soal, apa yang pertama kali dilakukan?

TS1 $002 \mathrm{~S}$ : Yang pertama saya lakukan, membaca soal kemudian menuliskan yang diketahui.

TS1 003 P : Dari soal, apa saja yang diketahui?

TS1 $004 \mathrm{~S}$ : Meja tulis divariabelkan sebagai $\boldsymbol{x}$ terus melalui tiga tahap, yaitu 2 jam, 1 jam dan 1 jam. Kemudian variabel $y$ meja makan memiliki waktu tahapan 1 jam, 2 jam, dan 1 jam. Tahap I itu yang diperlukan 180 jam, tahap II 165 jam, dan tahap III 115 jam, dan semuanya dalam 1 bulan itu 460 jam. Setiap meja memiliki keuntungan masing-masing 21.000 dan 27.000

TS1 005 P : Dari soal yang diberikan, apa yang ditanyakan?

TS1 006 S : Yang ditanyakan itu berapa banyak yang harus dibuat dalam 1 bulan untuk mendapatkan keuntungan meja tulis dan meja makan.

Berdasarkan hasil tes masalah 1 subjek TS dan wawancara mendalam diperoleh informasi bahwa subjek dapat menjelaskan informasi-informasi yang diperolehnya dari soal yang diberikan, kemudian subjek juga dapat mengemukakan kembali informasi yang diperolehnya sesuai dengan masalah yang diberikan secara lisan dan tulisan. Subjek terlebih dahulu membaca soal, kemudian memberikan prediksi dengan menuliskan informasi yang diperoleh secara singkat, serta memberikan penjelasan mengenai informasi dan bagan sederhana yang ditulisnya.

Hasil tes subjek TS pada masalah 1 dalam menetapkan tujuan, merencanakan apa yang akan dilakukan, memilih strategi yang tepat, dan mengurutkan tahap-tahap yang akan dilakukan dalam pemecahan masalah, ditampilkan dalam Gambar 10.

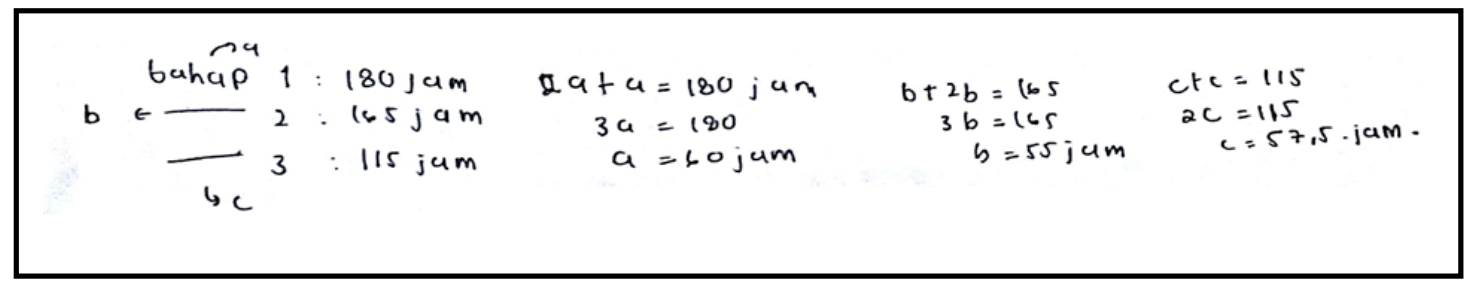

Gambar 10. Hasil Tes TS pada Masalah 1 untuk Komponen Planning

Gambar 10 menunjukkan subjek TS melakukan proses perencanaan penyelesaian masalah 1 dengan membuat beberapa persamaan yang akan digunakan dalam memecahkan masalah 1 serta terlihat juga beberapa langkah penyelesaian yang dipilih oleh TS. Hasil tes tersebut memperlihatkan bahwa terdapat komponen keterampilan metakognisi planning pada hasil penyelesaian HN untuk masalah 1.

Kutipan wawancara peneliti dengan subjek TS pada masalah 1 untuk komponen keterampilan metakognisi planning ditampilkan sebagai berikut:

TS1 007 P : Setelah menulis yang diketahui, apa lagi yang dilakukan?

TS1 008 S : Mencari waktu masing-masing tahap dari 460 jam ini. Variabel pada tahap I ditambahkan dan disama-dengan kan dengan 180 jam. Jadi didapat $a$ nya 60 jam, terus tahap II nya ditambahkan dan disama-dengan kan dengan 165 jam, didapat 55 jam. Tahap III juga ditambahkan terus disama-dengankan dengan 115 jam dan diperoleh $57.5 \mathrm{jam}$.

TS1 009 P : Mengapa harus membuat persamaan seperti ini?

\section{TS1 $010 \mathrm{~S}$ : Supaya dalam 460 jam ini bisa diketahui dalam 1 tahap itu dapat berapa jam.}

Berdasarkan hasil tes dan wawancara mendalam subjek HN diperoleh informasi bahwa subjek dapat melakukan proses perencanaan dan pemilihan strategi yang digunakannya dalam pemecahan masalah, kemudian subjek juga dapat menjelaskan kembali tahapan perencanaan serta strategi penyelesaian masalah yang dipilihnya. Subjek terlebih dahulu membuat persamaan berdasarkan informasi yang diperoleh dari soal, kemudian melakukan perencanaan melalui strategi yang akan digunakan, serta memberikan penjelasan mengenai perencanaan dan strategi yang ditulisnya. 
Hasil tes subjek TS dalam menilai hasil penyelidikan yang dilakukan, menilai pencapaian tujuan, menilai kesesuaian prosedur yang digunakan, dan membuat kesimpulan, ditampilkan dalam Gambar 11.

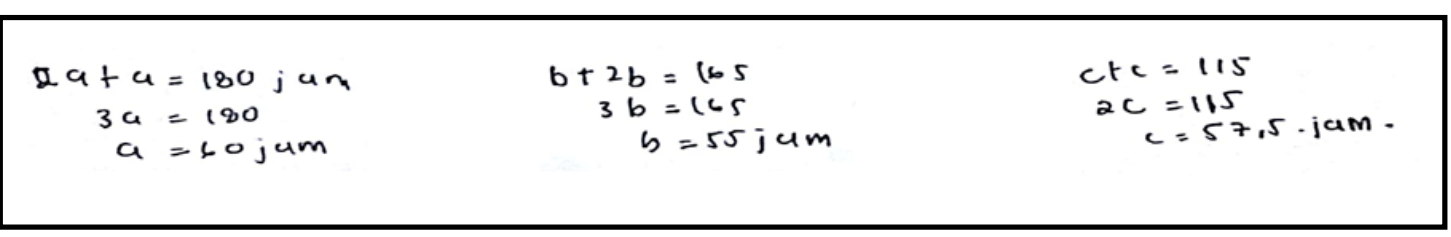

Gambar 11. Hasil Tes TS pada Masalah 1 untuk komponen keterampilan Evaluation

Gambar 11 menunjukkan subjek TS melakukan proses penilaian hasil pemecahan masalah berdasarkan prosedur dan langkah-langkah yang telah dilakukan. TS tidak membuat kesimpulan secara rinci, namun TS telah menentukan hasil penyelidikan dan perhitungan yang dilakukannya melalui pemecahan masalah, sehingga terlihat bahwa terdapat komponen keterampilan metakognisi evaluation pada hasil penyelesaian TS untuk masalah 1.

Kutipan wawancara peneliti dengan subjek TS pada masalah 1 untuk komponen keterampilan metakognisi evaluation ditampilkan sebagai berikut:

TS1 $011 \mathrm{P}$ : Jadi jawaban akhir yang diperoleh?

TS1 $012 \mathrm{~S}$ : 60 jam, 55 jam, dan $\mathbf{5 7 . 5}$ jam.

TS1 013 P : Apa makna dan kegunaan variabel $a, b$, dan $c$ ?

TS1 $014 \mathrm{~S}: \boldsymbol{a}, \boldsymbol{b}$, dan $\boldsymbol{c}$ itu menunjukkan tahap 1, tahap 2 dan tahap 3.

TS1 017 P : Kira-kira ini sudah selesai atau belum?

TS1 $018 \mathrm{~S}$ : Belum, tapi saya sudah tidak tau lagi lanjutannya kak, cuma sampai situ saya tau.

Berdasarkan hasil tes masalah 1 dan wawancara mendalam subjek TS diperoleh informasi bahwa subjek dapat menilai hasil penyelidikan yang dilakukan, dan menilai pencapaian tujuan dalam memecahkan masalah, kemudian subjek juga dapat menjelaskan kembali proses evaluation dan hasil yang diperolehnya. Subjek terlebih dahulu menilai kesesuaian prosedur dan langkah yang digunakan dalam memecahkan masalah, kemudian menentukan hasil penyelidikan berdasarkan prosedur yang dilakukan dan menilai pencapaian tujuan dari masalah yang diberikan, serta memberikan penjelasan mengenai proses evaluasi yang ditulisnya.

\subsection{Komponen Keterampilan Metakognisi Siswa Berkemampuan Tinggi (NF), Sedang (HN) dan Rendah (TS)}

\subsubsection{Komponen Keterampilan Metakognisi Siswa Berkemampuan Tinggi (NF)}

Hasil tes dan wawancara mendalam siswa berkemampuan tinggi menunjukkan bahwa subjek dapat menjelaskan informasi-informasi yang diperolehnya dari masalah yang diberikan. Subjek terlebih dahulu membaca soal, kemudian memberikan prediksi dengan cara membuat pemisalan, serta memberikan penjelasan mengenai informasi dan model matematika atau persamaan yang ditulisnya secara lisan. Hal ini menunjukkan terdapat komponen keterampilan metakognisi prediction pada pemecahan masalah siswa berkemampuan tinggi. Kemudian subjek dapat melakukan proses perencanaan dan penyusunan strategi yang akan digunakannya dalam pemecahan masalah. Subjek juga dapat menjelaskan kembali tahapan perencanaan serta strategi penyelesaian masalah yang dipilihnya. Subjek terlebih dahulu membuat pertidaksamaan berdasarkan informasi yang diperoleh dari soal, kemudian melakukan perencanaan melalui strategi yang akan digunakan, serta memberikan penjelasan mengenai perencanaan dan strategi yang ditulisnya. Hal ini menunjukkan terdapat komponen keterampilan metakognisi planning pada pemecahan masalah siswa berkemampuan tinggi.

Selanjutnya, subjek dapat memonitor langkah yang dilakukan dan memperbaiki kesalahan dalam memecahkanan masalah. Subjek juga dapat menjelaskan kembali tahapan keterampilan metakognisi monitoring dan langkah yang dipilihnya. Subjek terlebih dahulu melakukan perhitungan dan pengecekkan terhadap langkah yang dilakukannya, kemudian melakukan perbaikan jika terjadi kesalahan atau kekeliruan dalam memecahkan masalah, serta memberikan penjelasan mengenai proses monitoring yang ditulisnya. Hal ini menunjukkan terdapat komponen keterampilan monitoring pada pemecahan masalah siswa berkemampuan matematika tinggi. Kemudian subjek dapat menilai hasil penyelidikan yang dilakukan, menilai pencapaian tujuan, menilai kesesuaian prosedur yang 
digunakan, dan membuat kesimpulan dalam memecahkan masalah. Subjek juga dapat menjelaskan kembali proses evaluation dan kesimpulan yang dibuatnya. Subjek terlebih dahulu menilai kesesuaian prosedur dan langkah yang digunakan dalam memecahkan masalah, kemudian menentukan hasil penyelidikan berdasarkan prosedur yang dilakukan dan menilai pencapaian tujuan dari masalah yang diberikan, kemudian membuat kesimpulan akhir dari jawaban yang diperoleh, serta memberikan penjelasan mengenai proses evaluasi yang ditulisnya. Hal ini menunjukkan terdapat komponen keterampilan evaluation pada pemecahan masalah siswa berkemampuan matematika tinggi.

Kutipan rekaman video memperlihatkan bahwa dalam menyelesaikan masalah, NF memunculkan semua komponen-komponen keterampilan metakognisi secara berurutan bahkan terjadi siklus pola yang berulang, yakni dimulai dengan memprediksi (prediction) yang diperlihatkan ketika mengidentifikasi soal, selanjutnya ia mulai merencanakan (planning) penyelesaian yang akan digunakan, kemudian subjek NF memeriksa kembali hasil yang telah diperolehnya yang merupakan tahap keterampilan metakognisi monitoring, kemudian tahap keterampilan metakognisi evaluasi (evaluation) terlihat ketika NF telah memperoleh jawabannya. Selanjutnya terjadi pola yang berulang, yaitu kembali ke tahap keterampilan metakognisi monitoring, setelah itu subjek kembali ke tahap keterampilan metakognisi evaluasi (evaluation) Kemudian untuk menyelesaikan soal bagian b, NF kembali melakukan perencanaan penyelesaian (planning) yang akan digunakan, ketika merasa melakukan kekeliruan NF melakukan proses monitoring, dan yang terakhir adalah proses penyimpulan atau evaluasi (evaluation). Pola komponen keterampilan metakognisi yang terbentuk terlihat pada Gambar 12

Hasil identifikasi komponen keterampilan metakognisi pada siswa berkemampuan tinggi menunjukkan bahwa semua komponen keterampilan metakognisi muncul pada pemceahan masalah siswa berkemampuan tinggi dengan pola yang berurutan berulang, hasil penelitian ini memiliki kesamaan dengan teori yang dikemukakan oleh (Brown \& Baker, 1980; Intan Sari, 2016) bahwa ketika siswa memecahkan suatu masalah terdapat 4 komponen keterampilan metakognisi yang akan muncul yaitu prediction, planning, monitoring, dan evaluation. Selain itu, hasil ini sejalan dengan (Fatin Aliah Phang, 2006; Kuzle, 2013) dalam penelitiannya yang menyimpulkan bahwa siswa berkemampuan tinggi memiliki pola metakognisi yang lengkap, berurutan dan berulang. Selain itu, siswa berkemampuan tinggi memiliki komponen keterampilan metakognisi yang terdeskripsi dengan jelas dan rinci pada hasil pemecahan masalah yang dilakukan.

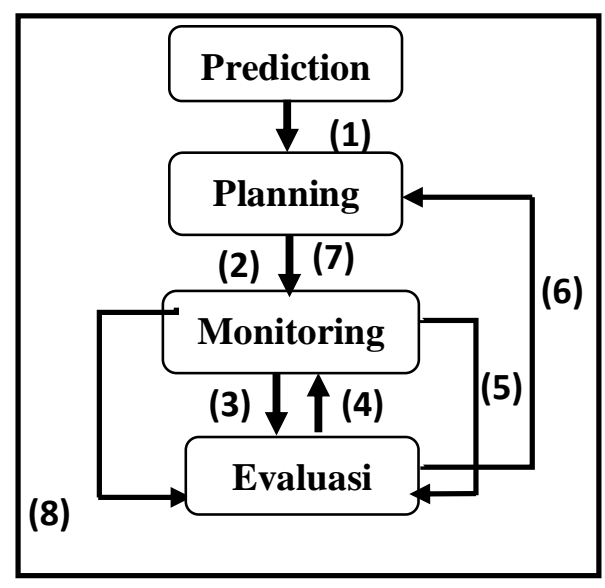

\section{Gambar 12. Pola Komponen Keterampilan Metakognisi NF}

\subsubsection{Komponen Keterampilan Metakognisi Siswa Berkemampuan Sedang (HN)}

Hasil tes subjek HN dan wawancara mendalam menunjukkan bahwa subjek dapat mengumpulkan informasi-informasi yang diperolehnya dari soal yang diberikan, kemudian subjek juga dapat mengemukakan kembali informasi yang diperolehnya sesuai dengan masalah yang diberikan. Informasi dalam tulisan HN tidak secara rinci memperlihatkan informasi yang diperolehnya, namun proses prediction tersebut terlihat pada hasil wawancara dan rekaman video. Subjek terlebih dahulu membaca soal, kemudian memberikan prediksi dengan menuliskan informasi yang diperoleh secara singkat, serta memberikan penjelasan mengenai informasi dan model matematika atau persamaan yang ditulisnya. Hal ini menunjukkan bahwa terdapat komponen keterampilan metakognisi prediction pada pemecahan masalah siswa berkemampuan matematika tinggi. Selanjutnya subjek HN dapat 
melakukan proses perencanaan dan strategi yang digunakannya dalam pemecahan masalah. Subjek juga dapat menjelaskan kembali tahapan perencanaan serta strategi penyelesaian masalah yang dipilihnya. Subjek terlebih dahulu membuat pertidaksamaan berdasarkan informasi yang diperoleh dari soal, kemudian melakukan perencanaan melalui strategi yang akan digunakan yaitu menggunakan grafik, serta memberikan penjelasan mengenai perencanaan dan strategi yang ditulisnya. Hal ini menunjukkan bahwa terdapat komponen keterampilan metakognisi planning pada pemecahan masalah siswa berkemampuan matematika sedang.

Subjek dapat memonitor langkah yang dilakukan dan memperbaiki kesalahan dalam memecahkan masalah. Subjek juga dapat menjelaskan kembali tahapan keterampilan metakognisi monitoring dan langkah yang dipilihnya. Subjek terlebih dahulu melakukan perhitungan dan pengecekkan terhadap langkah yang dilakukannya, kemudian melakukan perbaikan jika terjadi kesalahan atau kekeliruan dalam memecahkan masalah, serta memberikan penjelasan mengenai proses monitoring yang ditulisnya. Hal ini menunjukkan bahwa terdapat komponen keterampilan metakognisi monitoring pada pemecahan masalah siswa berkemampuan matematika sedang. Tahap akhir penyelesaian subjek HN menunjukkan subjek dapat menilai hasil penyelidikan yang dilakukan, menilai pencapaian tujuan, menilai kesesuaian prosedur yang digunakan, dan membuat kesimpulan dalam memecahkan masalah. Kemudian subjek juga dapat menjelaskan kembali proses evaluation dan kesimpulan yang dibuatnya. Subjek terlebih dahulu menilai kesesuaian prosedur dan langkah yang digunakan dalam memecahkan masalah, kemudian menentukan hasil penyelidikan berdasarkan prosedur yang dilakukan dan menilai pencapaian tujuan dari masalah yang diberikan, kemudian membuat kesimpulan akhir dari jawaban yang diperoleh, serta memberikan penjelasan mengenai proses evaluasi yang ditulisnya. Hal ini menunjukkan bahwa terdapat komponen keterampilan metakognisi evaluation pada pemecahan masalah siswa berkemampuan matematika sedang.

Kutipan video siswa berkemampuan sedang dalam memecahkan masalah memperlihatkan bahwa $\mathrm{HN}$ memunculkan semua komponen-komponen keterampilan metakognisi namun tidak berurutan dan terjadi siklus dengan pola yang berulang, yakni dimulai dengan merencanakkan (planning) proses awal yang akan digunakannya dalam menyelesaikan soal, selanjutnya ia mulai melakukan prediksi (prediction) yang akan ditunjukkan ketika mengidentifikasi soal. Setelah itu, HN kembali melakukan perencanaan (planning) yang ditunjukkan ketika merencanakan pertidaksamaan yang akan digunakan, setelah itu subjek HN memeriksa kembali hasil yang telah diperolehnya yang merupakan tahap keterampilan metakognisi monitoring, komponen keterampilan metakognisi yang muncul selanjutnya adalah Evaluasi (evaluation) yang terlihat ketika HN telah memperoleh jawabannya untuk bagian $a$, setelah itu HN kembali melakukan perencanaan (planning) untuk menyelesaikan bagian $b$. Perencanaan ini terlihat ketika HN memilih merubah dasawarsa ke dalam satuan "bulan" dibandingkan "tahun", sehingga hal ini menunjukkan bahwa HN sudah memiliki rencana untuk menyelesaikan masalah 1 bagian $b$. Kemudian, HN melakukan tahap keterampilan metakognisi monitoring dan memasuki tahap akhir yaitu tahap evaluasi (evaluation). Pola komponen keterampilan metakognisi yang terbentuk terlihat pada Gambar 13.

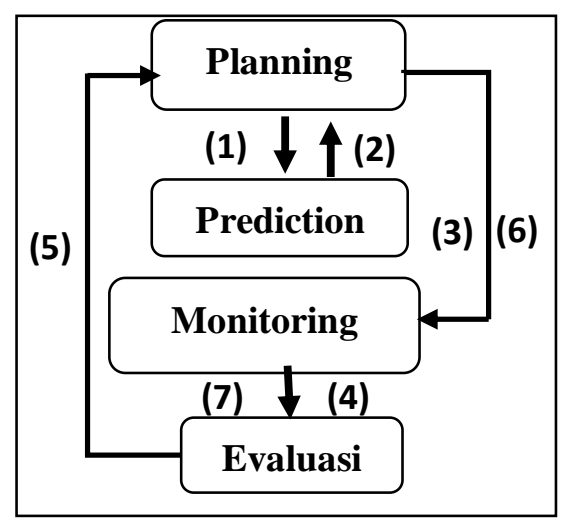

Gambar 13. Pola Komponen Keterampilan Metakognisi HN

Hasil penelitian ini memiliki kesamaan dengan teori yang dikemukakan oleh (Brown \& Baker, 1980; Intan Sari, 2016) bahwa ketika siswa memecahkan suatu masalah terdapat 4 komponen keterampilan metakognisi yang akan muncul yaitu prediction, planning, monitoring, dan evaluation. 
Selain itu, hasil penelitian untuk siswa berkemampuan sedang diperoleh bahwa semua komponen keterampilan metakognisi muncul pada pemecahan masalah siswa tersebut dengan pola yang tidak berurutan dan berulang, hasil ini sejalan dengan (Fatin Aliah Phang, 2006; Kuzle, 2013) dalam penelitiannya yang menyimpulkan bahwa siswa berkemampuan sedang memiliki pola metakognisi yang lengkap, tidak berurutan dan berulang. Selain itu, komponen keterampilan metakognisi yang dimiliki oleh siswa berkemampuan sedang terdeskripsi dengan jelas pada hasil pemecahan masalahnya, namun tidak begitu rinci seperti pada hasil pemecahan masalah siswa berkemampuan tinggi.

\subsubsection{Komponen Keterampilan Metakognisi Siswa Berkemampuan Rendah (TS)}

Hasil tes dan wawancara mendalam siswa berkemampuan rendah menunjukkan bahwa subjek dapat menjelaskan informasi-informasi yang diperolehnya dari soal yang diberikan, kemudian subjek juga dapat mengemukakan kembali informasi yang diperolehnya sesuai dengan masalah yang diberikan. Subjek terlebih dahulu membaca soal, kemudian memberikan prediksi dengan menuliskan informasi yang diperoleh secara singkat, serta memberikan penjelasan mengenai informasi dan bagan sederhana yang ditulisnya. Hal ini menunjukkan bahwa terdapat komponen keterampilan metakognisi prediction pada pemecahan masalah siswa berkemampuan rendah. Selanjutnya, subjek dapat melakukan proses perencanaan dan pemilihan strategi yang digunakannya dalam pemecahan masalah, kemudian subjek juga dapat menjelaskan kembali tahapan perencanaan serta strategi penyelesaian masalah yang dipilihnya. Subjek terlebih dahulu membuat persamaan berdasarkan informasi yang diperoleh dari soal, kemudian melakukan perencanaan melalui strategi yang akan digunakan, serta memberikan penjelasan mengenai perencanaan dan strategi yang ditulisnya. Hal ini menunjukkan bahwa terdapat komponen keterampilan planning pada pemecahan masalah siswa berkemampuan rendah. Kemudian hasil penyelesaian masalah subjek TS menunjukkan bahwa subjek dapat menilai hasil penyelidikan yang dilakukan, dan menilai pencapaian tujuan dalam memecahkan masalah, kemudian subjek juga dapat menjelaskan kembali proses evaluation dan hasil yang diperolehnya. Subjek terlebih dahulu menilai kesesuaian prosedur dan langkah yang digunakan dalam memecahkan masalah, kemudian menentukan hasil penyelidikan berdasarkan prosedur yang dilakukan dan menilai pencapaian tujuan dari masalah yang diberikan, serta memberikan penjelasan mengenai proses evaluasi yang ditulisnya. Hal ini menunjukkan bahwa terdapat komponen keterampilan evaluation pada pemecahan masalah siswa berkemampuan rendah.

Kutipan rekaman video memperlihatkan bahwa dalam menyelesaikan masalah yang diberikan subjek TS tidak memunculkan semua komponen-komponen keterampilan metakognisi dan tidak terjadi siklus dengan pola yang berulang, yakni dimulai dengan prediction yang diperlihatkan ketika TS mengidentifikasi soal, selanjutnya ia mulai melakukan perencanaan (planning), dan setelah itu TS langsung mencari penyelesaian yang merupakan tahap evaluation. Pola komponen keterampilan metakognisi yang terbentuk terlihat pada Gambar 14 .

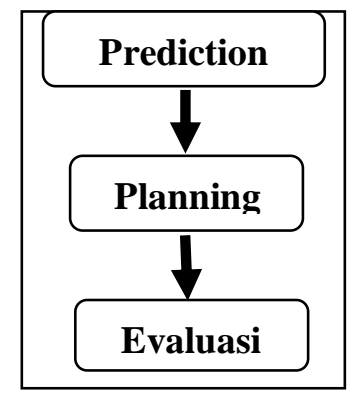

\section{Gambar 14. Pola Komponen Keterampilan Metakognisi TS}

Hasil penelitian untuk siswa berkemampuan rendah menunjukkan bahwa tidak semua komponen keterampilan metakognisi muncul dan pola yang ditunjukkan tidak berulang. Hal ini sejalan dengan (Fatin Aliah Phang, 2006) dalam penelitiannya yang menyimpulkan bahwa memeriksa kembali (monitoring) tidak dilakukan oleh setiap siswa, khususnya siswa yang berkemampuan rendah. Penyebabnya adalah proses memonitoring penyelesaian oleh siswa bukanlah hal yang mudah dilakukan, hal itu menuntut kesadaran siswa untuk mengecek dan mengoreksi jawabannya jika terjadi kesalahan pada saat poses pemecahan masalah, sehingga dapat disimpulkan bahwa komponen keterampilan metakognisi monitoring atau langkah memeriksa kembali jawaban adalah komponen 
yang harus diperkuat oleh para siswa dalam rangka meningkatkan kemampuan siswa dalam memecahkan masalah matematika.

\section{Simpulan}

Hasil penelitian ini menunjukkan bahwa subjek berkemampuan tinggi memunculkan semua komponen keterampilan metakognisi yaitu prediction, planning, monitoring, dan evaluation pada saat memecahkan masalah. Pola komponen keterampilan metakognisi siswa berkemampan tinggi adalah berurutan dan berulang. Kemudian subjek berkemampuan sedang juga memunculkan semua komponen keterampilan metakognisi yaitu prediction, planning, monitoring, dan evaluation pada saat memecahkan masalah, namun pola komponen keterampilan metakognisi siswa berkemampan sedang adalah tidak berurutan dan berulang. Selanjutnya subjek berkemampuan rendah memunculkan komponen keterampilan metakognisi yaitu prediction, planning, dan evaluation pada saat memecahkan masalah. Komponen keterampilan metakognisi yang tidak muncul pada saat siswa berkemampuan rendah memecahkan masalah adalah komponen monitoring (memeriksa kembali), sehingga pola komponen keterampilan metakognisi siswa berkemampuan rendah adalah tidak lengkap dan tidak berulang. Kepada para guru dianggap perlu untuk mengetahui dan melatih keterampilan metakognisi siswa dalam memecahkan masalah khususnya komponen keterampilan metakognisi yang dimiliki siswa, yaitu prediction, planning, monitoring, dan evaluation, agar indikator keterampilan siswa dalam menyelesaikan suatu permasalahan dapat terpenuhi.

\section{Referensi}

Brown, A. L., \& Baker, L. (1980). Metacognitive Skill and Reading. Bolt, Beranek and Newman, Inc. Cambridge, Mass.

Fatin Aliah Phang. (2006). The Patterns of Physics Problem-Solving From the Perspective of Metacognition [University of Cambridge]. https://www.academia.edu/298432/The_Patterns_of_Physics_Problem_Solving_From _the_Perspective_of_Metacognition

Hasibuan, E. K. (2018). Analisis Kesulitan Belajar Matematika Siswa Pada Pokok Bahasan Bangun Ruang Sisi Datar Di Smp Negeri 12 Bandung. AXIOM : Jurnal Pendidikan Dan Matematika, 7(1), 18-30. https://doi.org/10.30821/axiom.v7i1.1766

Intan Sari, M. (2016). Cognitive and Metacognitive Reading Strategy Use and Reading Comprehension Performance of Indonesian EFL Pre-service Teachers. Journal of Foreign Languange Teaching and Learning, 1(2). https://doi.org/10.18196/ftl.1213

J. H. Flavell. (1979). Metacognition and cognitive monitoring: A new area of cognitivedevelopmental inquiry. American Psychologist, 34(10), 906-911.

Kirkley, J. (2003). Principles for Teaching Problem Solving. Plato Learning Inc.

Kuzle, A. (2013). Patterns of metacognitive behavior during mathematics problem-solving in a dynamic geometry environment. International Electronic Journal of Mathematics Education, 8(1), 20-40.

Livingston, J. a. (2003). Metacognition: an overview. Psychology, 13, 259-266. http://gse.buffalo.edu/fas/shuell/CEP564/Metacog.htm

Miles, M. B., Huberman, A. M., \& Saldana, J. (2014). Qualitative Data Analysis: A Methods Sourcebook (3rd $\quad$ ed.). Sage https://books.google.co.id/books?id=p0wXBAAAQBAJ\&lpg=PP1\&hl=id\&pg=PR4\# $\mathrm{v}=$ onepage $\& \mathrm{q} \& \mathrm{f}=$ false

Niess, M. L. (2005). Preparing teachers to teach science and mathematics with technology: 
Developing a technology pedagogical content knowledge. Teaching and Teacher Education, 21(5), 509-523. https://doi.org/10.1016/j.tate.2005.03.006

Paul, R., \& Elder, L. (2005). A Guide For Educators to Critical Thinking Competency Standards: Standards, Principles, Performance Indicators, and Outcomes With a Critical Thinking Master Rubric. The Foundation for Critical Thinking. www.criticalthinking.org

Schoenfeld, A. H. (1985). Mathematical Problem Solving. Academic Press Inc. https://www.amazon.com/Mathematical-Problem-Solving-Alan-

Schoenfeld/dp/1493305999

Schoenfeld, A. H. (2016). Learning to Think Mathematically: Problem Solving, Metacognition, and Sense Making in Mathematics (Reprint). Journal of Education, 196(2), 1-38. https://doi.org/10.1177/002205741619600202

Stephanou, G., \& Mpiontini, M.-H. (2017). Metacognitive Knowledge and Metacognitive Regulation in Self-Regulatory Learning Style, and in Its Effects on Performance Expectation and Subsequent Performance across Diverse School Subjects. Psychology, 08(12), 1941-1975. https://doi.org/10.4236/psych.2017.812125

Telaumbanua, Y. N., Sinaga, B., Mukhtar, \& Surya, E. (2017). Development of Mathematics Module Based on Metacognitive Strategy in Improving Students' Mathematical Problem Solving Ability at High School. Journal of Education and Practice, 10(8), 12.

Yudha, F. (2019). Peran Pendidikan Matematika Dalam Meningkatkan Sumber Daya Manusia Guna Membangun Masyarakat Islam Modern. JPM: Jurnal Pendidikan Matematika, 5(2), 87. https://doi.org/10.33474/jpm.v5i2.2725 